\title{
Cardinal Symptoms of Cardiovascular Diseases: Dyspnea
}

\author{
Jyotsna Maddury ${ }^{1}$ \\ ${ }^{1}$ Department of Cardiology, NIMS, Punjagutta, Hyderabad, India
}

Indian J Cardiovasc Dis Women-WINCARS 2018;3:39-48

\section{Definition}

The American Thoracic Society defines dyspnea as a "subjective experience of breathing discomfort that consists of qualitatively distinct sensations that vary in intensity. The experience derives from interactions among multiple physiological, psychological, social, and environmental factors and may induce secondary physiological and behavioral responses." 1

Dyspnea is "synthetic sensation" such as thirst or hunger and is a result of complex interaction of signals arising from the central nervous system (CNS) (brainstem and motor cortex) and from a variety of receptors, in the respiratory and cardiovascular systems. Various terms have been used to express dissociation of motor command and mechanical response as "Length-tension inappropriateness" or "Neuromechanical dissociation" or "Efferent afferent dissociation."

\section{Mechanisms of Dyspnea}

\section{In General}

Respiratory sensations, either normal breathing or dyspnea, is due to interactions between the efferent and afferent pathways and the integrative processing of this information in the brain. The efferent or outgoing pathway is the motor output from the brain to the ventilatory muscles (feed-forward) and the afferent or incoming pathway is the sensory input from receptors from different parts of the body (feedback)

(-Fig. 1).

Dyspnea due to cardiovascular diseases is separately mentioned in the section of causes of dyspnea later. According to Campbell and Howell the sensation of dyspnea is due to dissociation between motor command and mechanical response of respiratory system.

\section{Cardiogenic Pulmonary Edema}

Increase in pulmonary venous pressure due to cardiac diseases leads to increase in hydrostatic pressure leading to leakage fluid into the interstitium. This causes first interstial edema, and in more severe cases to frank pulmonary edema causing
Address for correspondence Jyotsna Maddury, MD, DM, FACC, FESC, FICC, Department of Cardiology, NIMS, Punjagutta 500082, Hyderabad, (e-mail: mail2jyotsna@rediffmail.com).

respiratory distress. Additional pleural effusion due to cardiac failure further increases the respiratory distress.

Mechanisms of fluid accumulation and pulmonary edema leading to paroxysmal nocturnal dyspnea (PND) or orthopnea: The extent to which fluid accumulates in the interstitium of the lung depends on the balance of hydrostatic and oncotic forces within the pulmonary capillaries and in the surrounding tissue (-Fig. 2). Hydrostatic pressure favors movement of fluid from the capillary into the interstitium. The oncotic pressure, which is determined by the protein concentration in the blood, favors movement of fluid into the vessel. Levels of albumin, the primary protein in the plasma that determines oncotic pressure may be low in conditions such as cirrhosis and nephrotic syndrome. While hypoalbuminemia favors movement of fluid into the tissue for any given hydrostatic pressure in the capillary, it is usually not sufficient by itself to cause interstitial edema. In a healthy individual, the tight junctions of the capillary endothelium are impermeable to proteins, and the lymphatics in the tissue carry away the small amounts of protein that may leak out; together, these factors result in an oncotic force that maintains fluid in the capillary. Disruption of the endothelial barrier-capillary permeability, however, allows protein to escape the capillary bed and enhances the movement of fluid into the tissue of the lung tissue.

Early signs of increased pulmonary capillary pressure include exertional dyspnea and orthopnea. Chest radiographs show redistribution of blood in the upper lung zones, peribronchial thickening, and Kerley B lines. As the pulmonary edema worsens, alveoli fill with fluid with the chest radiograph showing patchy alveolar filling, typically in a perihilar distribution, which then progresses to diffuse alveolar infiltrates. Increasing airway edema is associated with rhonchi and wheezes.

Occasionally, patients with pulmonary congestion caused by heart failure have insomnia before they develop nocturnal dyspnea. ${ }^{2}$ Pulmonary dysfunction is common in patients with heart failure and can also contribute to exercise intolerance. The amount of intrathoracic space available 


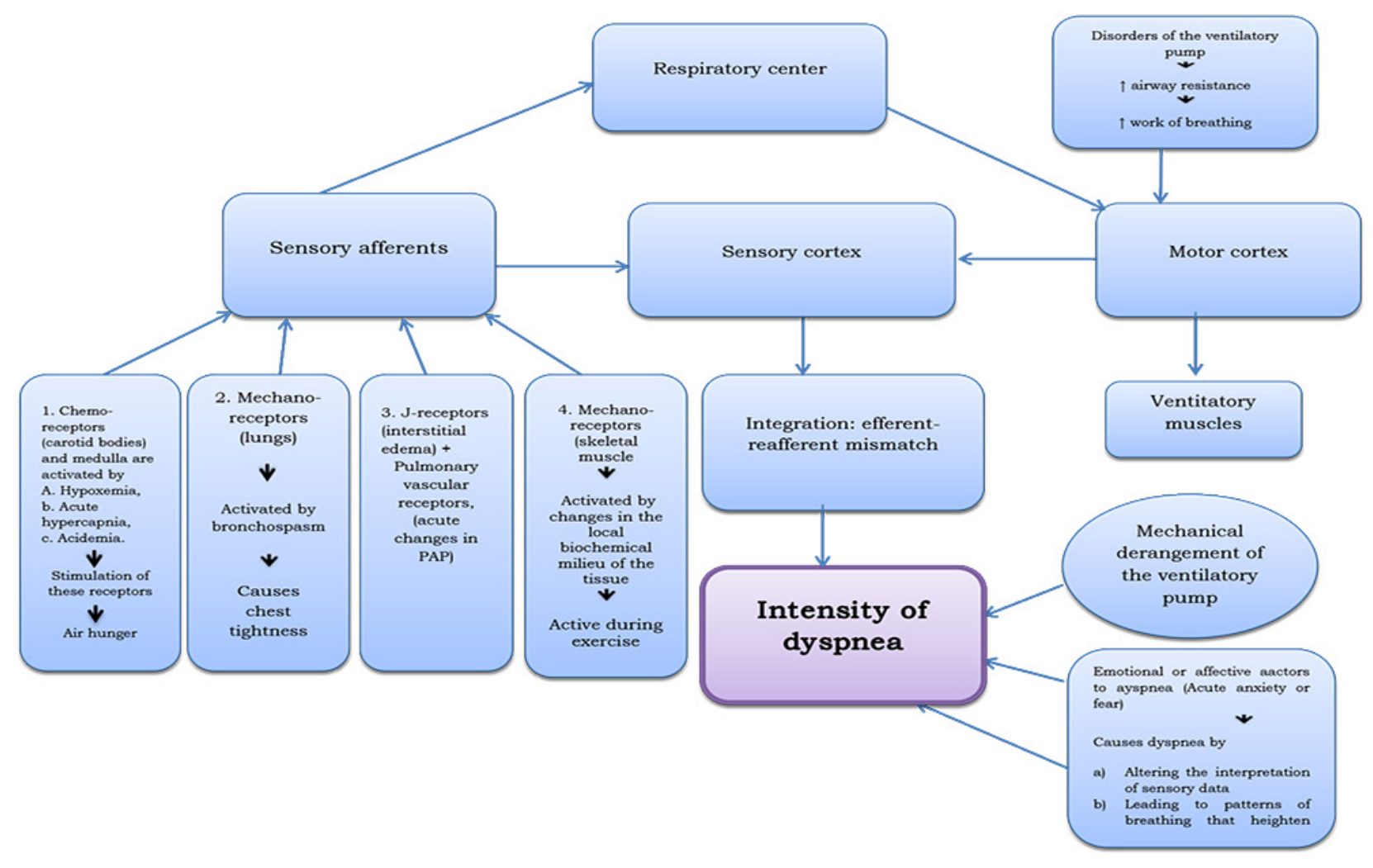

Fig. 1 Mechanism of dyspnea.

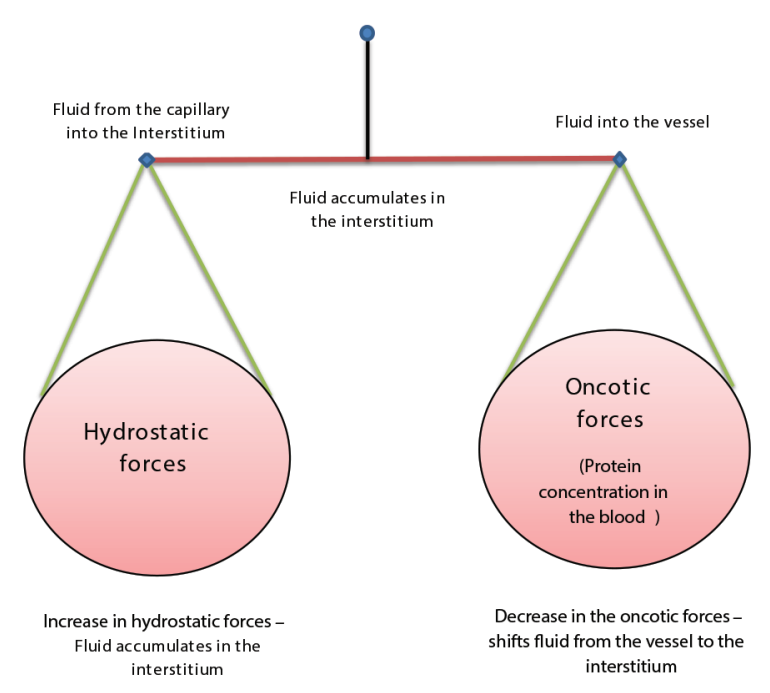

Fig. 2 Factors influencing shift of fluid from the vessel to interstitium and vice versa.

for ventilation can be decreased by alveolar and interstitial edema, pleural effusions, or by an increase in blood volume. Increased pulmonary vascular congestion decreases lung compliance and increases the work of breathing. Excessive ventilation, including an increased $\mathrm{VE} / \mathrm{VO}_{2}$ slope during exercise, is a hallmark of heart failure and has important prognostic implications. An acute reduction in pulmonary capillary wedge pressure has no effect on the augmented ventilatory response, and the extent of excessive ventilation does not relate to either resting or exercise pulmonary capillary wedge pressure. ${ }^{3}$

\section{Noncardiogenic Pulmonary Edema}

In noncardiogenic pulmonary edema, primarily there is increased capillary permeability with consequent leakage of proteins and other macromolecules into the interstitium causing the increase in oncotic pressures in the interstitium. So, intravascular fluid also enters into interstitium. Along with this there is a surfactant dysfunction causing increased surface force which leads to collapse of alveoli at low lung volumes. In addition, more severe hypoxia occurs in noncardiogenic pulmonary edema due to intrapulmonary shunt and decreased pulmonary compliance leading to lower functional residual capacity.

In this condition patient can develop mild dyspnea to respiratory failure. Clinical signs of crackles on lung auscultation are present on extent of the diseases.

\section{Possible Mechanisms of Dyspnea in Different Diseases}

Heart failure: Increased work of breathing.

Hypoxia due to ventilation/perfusion $(\mathrm{V} / \mathrm{Q})$ mismatch.

Acidosis due to decreased output.

Pulmonary Embolism: Stimulation of pressure receptors in pulmonary artery (PA) vasculature and right atrium (RA). Chronic obstructive pulmonary disease (COPD): Increased sense of effort. Hypoxia. Hypercapnia. Dynamic airway compression. 
Neuromuscular disorders: Increased sense of effort. Mechanical ventilation: Afferent mismatch.

\section{Types of Dyspnea}

1. Dyspnea may occur with exertion.

2. Dyspnea on recumbency (orthopnea).

3. Dyspnea with standing (platypnea).

4. Paroxysmal Nocturnal Dyspnea of cardiac origin usually occurs 2 to 4 hours after the onset of sleep. Patient has to sit upright or stand to get relief from dyspnea. Even after assuming sitting posture, dyspnea takes several minutes to normalize. History of snoring and apnic episode from the patient's partner is essential. ${ }^{4}$ Although orthopnea and PND are relatively specific for heart failure, they are not sensitive for a diagnosis of heart failure. ${ }^{5}$

5. Bendopnea/Kamptropnea- (kamptros-bend over)-bend forward while sitting for 30 seconds then dyspnea develops. This is a sign of advanced heart failure. Bending forward leading to elevation of filling pressures in RA/LA along with upward displacement and compression of the liver (akin to hepatojugular reflux), generally associated with decreased cardiac index (CI).

\section{Assessing Dyspnea}

The patient may describe the dyspnea in different ways such as air hunger or urge to breath, or inability to get deep breath, or unsatisfying breath, or heavy breathing, or rapid breathing, or increased effort of breathing. We can take the history of dyspnea whether it is present at rest, immediately following exercise, or on recall of a reproducible physical task, such as climbing the stairs at home. An alternative approach is to gain a sense of the patient's disability by inquiring about what activities are possible. These methods indirectly assess dyspnea and may be affected by nonrespiratory factors, such as leg arthritis or weakness. Therefore, to know the severity dyspnea, different scoring systems are there.

Dyspnea is a subjective symptom and is influenced by the intensity of muscular activity, resulting in increased oxygen uptake and increased $\mathrm{CO}_{2}$ output. Dyspnea intensifies as the inspiratory reserve decreases, for any given muscular activity. Dyspnea index is the ratio of exercise ventilation to maximal voluntary ventilation (MVex/MVv).

In the assessment of severity of dyspnea, ventilatory capacity is measured before exercise and ventilation is measured during exercise, and these are related to intensity of dyspnea, using either modified Borg scale or visual analog scale (VAS). More commonly physicians and cardiologists in particular use the NYHA (New York Heart Association) class or specific activity scale of Goldman to assess the severity of dyspnea (- Table $\mathbf{1}$ ). Other scales are mentioned in - Tables 2, 3 and - Fig. 3.

\section{Causes of Dyspnea}

Dyspnea most often results from deviations from normal function in the cardiovascular, respiratory systems and neuromuscular disorders. These deviations produce breathlessness as a consequence of increased drive to breathe; increased effort or work of breathing; and/or stimulation of receptors in the heart, lungs, or vascular system.

Common to all these disorders is increased work of breathing, consequent to airway disease, parenchymal lung disease, etc. and decreased compliance for cardiovascular disorders. (secondary to pulmonary venous congestion resulting in increased extravascular fluid in lung parenchyma).

Other mechanisms include abnormal gas exchange (leading to hypoxia), inadequate cardiac output at rest/on effort

Table 1 Stages in NYHA and SAS ${ }^{6}$

\begin{tabular}{|c|c|c|}
\hline Stage & NYHA functional classification & Specific activity scale \\
\hline I & $\begin{array}{l}\text { Patients with cardiac disease but without resulting } \\
\text { limitations of physical activity. Ordinary physical } \\
\text { activity does not cause undue fatigue, palpitation, } \\
\text { dyspnea, or anginal pain. }\end{array}$ & $\begin{array}{l}\text { Patients can perform to completion any activity requiring } \\
>7 \text { METs (e.g., can carry } 24 \text { lb up eight steps; carry objects } \\
\text { that weigh } 80 \text { lb; do outdoor work [shovel snow, spade soil]; } \\
\text { do recreational activities [skiing, basketball, squash, hand- } \\
\text { ball, jog/walk } 5 \text { mph]). }\end{array}$ \\
\hline II & $\begin{array}{l}\text { Patients with cardiac disease resulting in slight } \\
\text { limitation of physical activity. They are comfortable } \\
\text { at rest. Ordinary physical activity results in fatigue, } \\
\text { palpitation, dyspnea, or angina pain. }\end{array}$ & $\begin{array}{l}\text { Patients can perform to completion any activity requiring } \\
>5 \text { METs (e.g., have sexual intercourse without stopping, } \\
\text { garden, rake, weed, roller skate, dance fox trot, walk at } 4 \\
\text { mph on level ground), but cannot and do not perform to } \\
\text { completion activities requiring } 28 \text { METs. }\end{array}$ \\
\hline III & $\begin{array}{l}\text { Patients with cardiac disease resulting in marked } \\
\text { limitation of physical activity. They are comfortable } \\
\text { at rest. Less-than-ordinary physical activity causes } \\
\text { fatigue, palpitation, dyspnea, or anginal pain. }\end{array}$ & $\begin{array}{l}\text { Patients can perform to completion any activity requiring > } \\
2 \text { METs (e.g., shower without stopping, strip and make bed, } \\
\text { clean windows, walk } 2.5 \text { mph, bowl, play golf, dress without } \\
\text { stopping), but cannot and do not perform to completion } \\
\text { any activities requiring }{ }^{26} \text { METs. }\end{array}$ \\
\hline IV & $\begin{array}{l}\text { Patients with cardiac disease resulting in inability to } \\
\text { carry on any physical activity without discomfort. } \\
\text { Symptoms of cardiac insufficiency or of the anginal } \\
\text { syndrome may be present even at rest. If any physi- } \\
\text { cal activity is undertaken, discomfort is increased. }\end{array}$ & $\begin{array}{l}\text { Patients cannot or do not perform to completion activities } \\
\text { requiring }{ }^{36} \text { METs; cannot carry out activities listed above } \\
\text { (SAS, class III). }\end{array}$ \\
\hline
\end{tabular}

Abbreviations: MET, metabolic equivalent; NYHA, New York Heart Association; SAS, Specific Activity Scale. 
Table 2 Modified Borg scale for severity of dyspnea

\begin{tabular}{|c|c|}
\hline \multicolumn{2}{|r|}{ A. Modified Borg scale-Burden et al } \\
\hline Grade & Severity of dyspnea \\
\hline 0 & Nothing at all \\
\hline 0.5 & Very very slight (just noticeable) \\
\hline 1 & Very slight \\
\hline 2 & Slight \\
\hline 3 & Moderate \\
\hline 4 & \\
\hline 5 & Severe \\
\hline 6 & \\
\hline 7 & Very severe \\
\hline 8 & \\
\hline 9 & Very very severe (almost maximal) \\
\hline 10 & Maximal \\
\hline & B. Modified Borg scale-Kendrick et al \\
\hline Grade & Severity of dyspnea \\
\hline 0 & No breathlessness al all \\
\hline 0.5 & Very very slight (just noticeable) \\
\hline 1 & Very slight \\
\hline 2 & Slight breathlessness \\
\hline 3 & Moderate \\
\hline 4 & Somewhat severe \\
\hline 5 & Severe \\
\hline 6 & \\
\hline 7 & Very severe breathlessness \\
\hline 8 & \\
\hline 9 & Very very severe (almost maximal) \\
\hline 10 & Maximal \\
\hline
\end{tabular}

Table 3 Baseline dyspnea index

\begin{tabular}{|l|l|}
\hline Scale & Severity \\
\hline 1 & Breathless with strenuous exercise. \\
\hline 2 & $\begin{array}{l}\text { Short of breath when hurrying on the level } \\
\text { surface or walking up a slight hill. }\end{array}$ \\
\hline 3 & $\begin{array}{l}\text { Walks slower than people of the same age on a } \\
\text { level surface because of breathlessness } \\
\text { (I have to stop or I have to stop for breath when } \\
\text { walking at my own pace on the level surface.) }\end{array}$ \\
\hline 4 & $\begin{array}{l}\text { Stops for breath after walking for } 100 \text { m or a few } \\
\text { minutes on a level surface. }\end{array}$ \\
\hline 5 & $\begin{array}{l}\text { Too breathless to leave the house or I am } \\
\text { breathless dressing and undressing. }\end{array}$ \\
\hline
\end{tabular}

resulting increase in lactate contributing to sensation of dyspnea.

Stimulation of mechanoreceptors, chemoreceptors in skeletal muscle, and pulmonary vasculature may cause sensation of dyspnea.
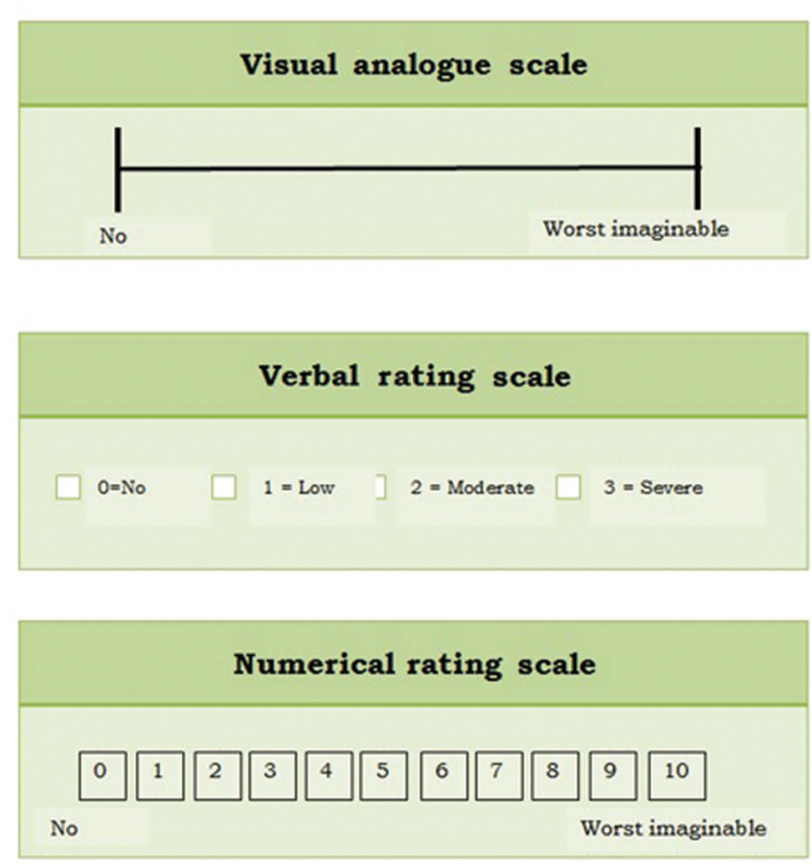

Fig. 3 Visual analogue scale.

A. Respiratory causes: Most diseases of the respiratory system are associated with alterations in the mechanical properties of the lungs and/or chest wall, and some stimulate pulmonary receptors. Patients with acute bronchoconstriction also report a sense of tightness, which can exist even when lung function is still within the normal range. These patients are commonly tachypneic.

B. Cardiac causes: Disorders of the cardiovascular system more commonly lead to dyspnea by causing gas-exchange abnormalities or stimulating pulmonary and/or vascular receptors. Mechanism of dyspnea due to left heart disease (systolic and diastolic dysfunction):

1. This is due to elevation of the left-ventricular end-diastolic pressure as well as pulmonary capillary pressures. These elevated pressures lead to interstitial edema and stimulation of pulmonary receptors, thereby causing dyspnea

2. Hypoxemia due to $\mathrm{V} / \mathrm{Q}<1$ mismatch may also contribute to breathlessness.

C. Diseases of the pulmonary vasculature:

1. Pulmonary thromboembolic disease and primary diseases of the pulmonary circulation (primary pulmonary hypertension, pulmonary vacuities). Pulmonary embolism often causes dyspnea of sudden onset. ${ }^{4}$ Dyspnea in pulmonary thromboendarterectomy (PTE) is often out of proportion to any derangement in respiratory mechanics or gas exchange. The most likely possibility is stimulation of pressure receptors in pulmonary vasculature/RA or C fibers in pulmonary vessels mediating sensation of dyspnea.

2. In pulmonary arterial hypertension (PAH) the mechanism of dyspnea is due to increased pulmonaryartery pressure and stimulation of pulmonary receptors. 
Hyperventilation is common, and hypoxemia may be present. However, in most cases, use of supplemental oxygen has only a minimal impact on the severity of dyspnea and hyperventilation. Patients with advanced PAH can have increased left ventricular (LV) filling pressures that contribute to the symptoms of dyspnea and orthopnea, which can be relieved with diuretics. Dyspnea, the most frequent presenting complaint in patients with $\mathrm{PAH}$, is the consequence of low cardiac output, resulting in poor delivery during physical activity as a result of markedly elevated postvoid residual urine volume (PVR). ${ }^{7.8}$

D. Anemia: Dyspnea with mild to moderate anemia is associated with breathing discomfort during exercise. This symptom is thought to be related to stimulation of mechanoreceptors; oxygen saturation is normal in patients with anemia.

E. Obesity: Breathlessness associated with obesity is probably due to multiple mechanisms, including high cardiac output and impaired ventilatory pump function (decreased compliance of the chest wall). Cardiovascular deconditioning (poor fitness) is characterized by the early development of anaerobic metabolism and stimulation of chemoreceptors and metaboreceptors.

F. Dyspnea that is medically unexplained:

1. This has been associated with increased sensitivity to the unpleasantness of acute hypercapnia. When hypoxemia is present, dyspnea usually persists, albeit at a reduced intensity, with correction of hypoxemia by administration of supplemental oxygen.

2. Patients with tamponade may complain of true dyspnea, whose mechanism is uncertain because there is no pulmonary congestion. They almost always are more comfortable sitting forward. ${ }^{9}$

3. During normal pregnancy, women often experience fatigue, dyspnea, tachypnea, palpitations, presyncope, and decreased exercise tolerance. ${ }^{10}$

G. Rare causes of dyspnea

1. A better way to determine whether exercise is limited by ventilation is by measurement of tidal flow-volume loops during exercise, which may have the added advantage of detecting vocal cord dysfunction, an increasingly recognized cause of exertional dyspnea. ${ }^{11}$

2. Abernethy malformation because its initial presentation is one of dyspnea and cyanosis rather than of frank liver disease. Malformation is due to congenital absence of the portal vein, which results in a diversion of portal blood away from the liver and directly into the vena cava. ${ }^{12}$

3. Vocal cord dysfunction is paradoxical adduction of vocal cords during inspiration, inducing glottic occlusion resulting in clinical picture of obstructive airway disease.

H. Dyspnea due to drugs:

1. Adenosine.

2. Ticagrelor-Dyspnea due to this drug may be adenosine mediated. Ticagrelor can produce ventricular pauses exceeding 5 seconds. ${ }^{13}$
3. $\beta$-Agonists. ${ }^{14}$

4. Amiadarone ${ }^{15}$ due to pulmonary toxicity.

I. Physiologic dyspnea: In a maximal exercise test to voluntary exhaustion, most healthy patients cease exercise because of leg discomfort or fatigue, though some will complain of dyspnea, as the reason(s) for being unable to continue. This presumably reflects leg muscle fatigue, where $\mathrm{O}_{2}$ demand exceeds $\mathrm{O}_{2}$ supply to (or utilization by) muscle mitochondria. ${ }^{16}$

\section{Approach to the Patient}

\section{History}

History of dyspnea includes the duration, severity, precipitating or aggravating as well as relieving factors such as the effect of position, infections, and environmental stimuli.

Orthopnea is seen in:

1. Congestive heart failure (CHF).

2. Mechanical impairment of the diaphragm associated with obesity.

3. Asthma triggered by esophageal reflux.

Nocturnal dyspnea suggests:

1. CHF.

2. Asthma.

Severe and sudden-onset dyspnea indicates acute pulmonary edema, typically precipitated by ${ }^{17}$ :

1. Ischemia.

2. Arrhythmia.

3. Sudden left-sided valvular regurgitation.

4. Accelerated hypertension.

Acute, intermittent episodes of dyspnea:

1. Episodes of myocardial ischemia.

2. Bronchospasm.

3. Pulmonary embolism.

Chronic persistent dyspnea is seen in:

1. Chronic obstructive pulmonary disease (COPD).

2. Interstitial lung disease.

3. Chronic thromboembolic disease.

When the patient complains of platypnea, that is, dyspnea in the upright position with relief in the supine position:

1. Left atrial myxoma.

2. Hepatopulmonary syndrome.

3. Platypnea-orthodeoxia syndrome (dyspnea and arterial desaturation in the upright position, which improves on lying down) has also been attributed to the presence of a patent foramen ovale (PFO). ${ }^{18}$

Exertional dyspnea: Effort dyspnea and fatigue reflect an inadequate increment in cardiac output and an increase in LV end-diastolic pressure. ${ }^{19}$

1. Anginal equivalents mean symptoms of myocardial ischemia other than angina. Especially in elderly patients the myocardial ischemia may express as dyspnea, faintness, 
fatigue, and eructations instead of typical angina. ${ }^{20}$ Even in hibernating myocardium condition the myocardial ischemia may manifest as dyspnea rather than angina. This is due to abnormal systolic or diastolic LV function or both in this hibernating myocardium. ${ }^{21}$

2. Many of left and right heart diseases: In an important subset of patients with diastolic dysfunction, pulmonary capillary wedge pressure is normal at rest but increases only with exertion, causing exertional dyspnea. However, in patients with diastolic dysfunction and exertional dyspnea, E velocity increases with exercise, but $\mathrm{E}_{\mathrm{a}}$ velocity remains less or increases less with exercise. Therefore, the E/e' ratio increases with exercise compared with the resting stage in patients with diastolic dysfunction. ${ }^{22}$

3. Pulmonary parenchymal and vascular diseases: On exercise, there is transient increase in pulmonary artery pressures.

4. Elderly patients with hypertension treated with vasodilators, diuretics, or digoxin may develop dynamic obstruction and associated symptoms of dyspnea, chest pain, or hypotension exacerbated by treatment. This disorder has been called hypertensive hypertrophic cardiomyopathy (HCM), but it is clearly different from true HCM. Dynamic left ventricular outflow tract (LVOT) obstruction is also commonly noted in the postoperative period when intravascular volume is depleted and inotropic agents are being administered. Patients with aortic stenosis (AS) or mitral valve prolapse are especially vulnerable to LVOT obstruction after aortic valve replacement or mitral valve repair, respectively. Acute LVOT obstruction can occur after acute anterior-apical MI, and some patients with apical ballooning have dynamic LVOT obstruction caused by systolic anterior motion of mitral valve (SAM) and associated mitral regurgitation (MR). Discrete subaortic stenosis can mimic hypertrophic obstructive cardiomyopathy; however, a continuous-wave Doppler recording of subaortic stenosis does not demonstrate a dynamic late-peaking profile but resembles that of valvular AS. Dynamic LVOT obstruction may also be an initial presentation of cardiac amyloidosis. $^{23}$

5. Many hyperthyroid patients experience exercise intolerance and exertional dyspnea, caused in part by skeletal and respiratory muscle weakness. ${ }^{24}$

6. According to the Framinghom criteria for diagnosis of heart failure, PND or orthopnea is a major criterion and exertional dyspnea is a minor criterion. ${ }^{25}$

\section{Physical Examination}

1. If patient not able to complete a sentence without taking deep breaths, it means there is significant decreased vital capacity.

2. Evidence of increased work of breathing (supraclavicular retractions; use of accessory muscles of ventilation; and the tripod position, characterized by sitting with the hands braced on the knees) is indicative of increased airway resistance or stiffness of the lungs and the chest wall.
3. Pulsus paradoxus - the presence of COPD, acute asthma, or pericardial disease.

4. In the ESCAPE (Evaluation Study of Congestive Heart Failure and Pulmonary Artery Catheterization Effectiveness) trial, an estimated RA pressure $>12 \mathrm{~mm} \mathrm{Hg}$ and two-pillow orthopnea were the only bedside parameters (including gastrointestinal distress, fatigue, dyspnea, rales, ascites, edema, and hepatomegaly) that provided incremental value in predicting a PA wedge pressure $>22 \mathrm{~mm} \mathrm{Hg}$ and compared favorably with brain natriuretic peptide levels. ${ }^{26}$

\section{General Examination}

In dyspneic patient specifically we have to check for the presence of anemia (as the cause of dyspnea), cyanosis (may be due to severe respiratory failure of cyanotic congenital heart disease), and presence of spider naevi or gynecomastia (suggestive of cirrhosis).

\section{Examination of the Chest}

1. For respiratory cause: Symmetry of chest movement, percussion (dullness is indicative of pleural effusion; hyperresonance is a sign of emphysema), and auscultation (wheezes, rhonchi, prolonged expiratory phase, and diminished breath sounds are clues to disorders of the airways; rales suggest interstitial edema or fibrosis).

2. For the cardiac cause: Examination should focus on presence and severity of cardiac valvular heart disease, bibasal rales, and infrequently pulsus alternans. Additionally, presence of palpable and audible "third heart sound" should alert to possibility of cardiac cause of dyspnea.

3. Signs of elevated right heart pressures (jugular venous distention, edema, accentuated pulmonic component to the second heart sound), left heart dysfunction (S3 and S4 gallops), and valvular disease (murmurs).

\section{Abdominal Examination}

When examining the abdomen with the patient in the supine position, the physician should note whether there is inspiratory inward movement of the abdomen indicating diaphragmatic paralysis.

Dynamic auscultation might bring out latent heart disease just as positive hepatojugular reflux might confirm the presence of incipient heart disease.

\section{Investigations}

1. Chest imaging.

a. Prominent pulmonary vasculature in the upper zones indicates pulmonary venous hypertension.

b. Enlarged central pulmonary arteries suggest PAH.

c. An enlarged cardiac silhouette suggests dilated cardiomyopathy or valvular disease.

d. Bilateral pleural effusions are typical of CHF and some forms of collagen-vascular disease.

e. Unilateral effusions raise the specter of carcinoma and pulmonary embolism but may also occur in heart failure. 
f. Chest ultrasound for "comets"-US equivalent of Kerley' s lines-thickened interalveolar septae.

2. Laboratory studies.

a. Electrocardiography (ECG) to seek evidence of ventricular hypertrophy and prior myocardial infarction. According to ACC/AHA (American College of Cardiology/American Heart Association) guidelines for ECG in patients with known cardiovascular disease is class I indication to take ECG in follow-up when the patient has worsening dyspnea. ${ }^{27}$ It is unusual to have absolutely normal ECG in patients having CHF.

b. Echocardiography is indicated when systolic dysfunction, pulmonary hypertension, or valvular heart disease is suspected.

c. Measurement of brain natriuretic peptide levels in serum. ${ }^{28}$ According to ACC/AHA recommendation for hospitalized patients, B-type natriuretic peptide (BNP) or N-terminal pro-BNP (NT-pro BNP) should be measured to evaluate dyspnea if the contribution of heart failure is not known is class I with level A evidence. ${ }^{29}$

\section{Differentiation of Cardiogenic versus Noncardiogenic Pulmonary Edema}

These differences are summarized in - Table 4 .

\section{Differentiating Cardiovascular from Respiratory System Dyspnea}

If a patient has evidence of both pulmonary and cardiac disease, a cardiopulmonary exercise test should be performed to determine which system is responsible for the exercise limitation.

1. If, at peak exercise, the patient achieves predicted maximal ventilation, demonstrates an increase in dead space or hypoxemia, or develops bronchospasm, the respiratory system is probably the cause of the problem.
2. If the heart rate is $>85 \%$ of the predicted maximum, anaerobic threshold occurs early, blood pressure becomes excessively high or decreases during exercise, if the $\mathrm{O}_{2}$ pulse $\left(\mathrm{O}_{2}\right.$ consumption/heart rate, an indicator of stroke volume) falls, or if there are ischemic changes on the ECG, an abnormality of the cardiovascular system is likely the explanation for the breathing discomfort.

\section{Dyspnea in Specific Diseases}

1. Total anomalous pulmonary venous connection with obstruction: Dyspnea may be accentuated by straining and swallowing due to interference of pulmonary venous outflow by increased intra-abdominal pressure or impingement of the esophagus on the common pulmonary vein as it exits through the esophageal hiatus. $^{30}$

2. In bacterial pericarditis: Patients have dyspnea, tachypnea, and tachycardia out of proportion to the fever. ${ }^{31}$

3. Mitral regurgitation: Although the exact mechanisms of dyspnea in MR are not entirely understood, dyspnea correlates best with elevated left atrial pressure. ${ }^{32}$

4. Atrial septal defect (ASD): Dyspnea and fatigue are early symptoms of an ostium secundum ASD. The large leftto-right shunt is responsible for a decrease in pulmonary compliance and an increase in the work of breathing. Orthopnea may be experienced because the supine position increases the work of breathing in patients with reduced lung compliance. ${ }^{33}$

5. Cyanotic congenital heart disease: Cardiorespiratory responses to isotonic exercise in cyanotic congenital heart disease significantly influence the dynamics of oxygen uptake and ventilation. Prolonged onset and recovery of oxygen uptake kinetics incur large oxygen deficits that result in hypoxemia even with low levels of exercise, which suggests that patients with right-to-left shunts

Table 4 Distinguishing cardiogenic from noncardiogenic pulmonary edema

\begin{tabular}{|c|c|}
\hline Cardiogenic pulmonary edema & Non-cardiogenic pulmonary edema \\
\hline \multicolumn{2}{|l|}{ History } \\
\hline Previous history of cardiac disease & $\begin{array}{l}\text { History suggestive of different causes for Non-cardiogenic } \\
\text { pulmonary edema }\end{array}$ \\
\hline \multicolumn{2}{|l|}{ Physical examination } \\
\hline $\begin{array}{l}\text { Evidence of increased intracardiac pressures (S3 gallop, } \\
\text { elevated jugular venous pulse, peripheral edema) and } \\
\text { rales and/or wheezes on auscultation of the chest }\end{array}$ & $\begin{array}{l}\text { The findings of the precipitating condition } \\
\text { Pulmonary findings may be relatively normal in the early stages }\end{array}$ \\
\hline \multicolumn{2}{|l|}{ Chest radiograph } \\
\hline $\begin{array}{l}\text { 1. Enlarged cardiac silhouette } \\
\text { 2. Vascular redistribution } \\
\text { 3. Interstitial thickening } \\
\text { 4. Perihilar alveolar infiltrates } \\
\text { 5. Pleural effusions are common }\end{array}$ & $\begin{array}{l}\text { 1. Heart size is normal } \\
\text { 2. Alveolar infiltrates are distributed more uniformly through- } \\
\text { out the lungs } \\
\text { 3. Pleural effusions are uncommon }\end{array}$ \\
\hline \multicolumn{2}{|l|}{ Effect of oxygen supplementation } \\
\hline $\begin{array}{l}\text { The hypoxemia is due largely to } V / Q \text { to mismatch and } \\
\text { responds to the administration of supplemental oxygen }\end{array}$ & $\begin{array}{l}\text { The hypoxemia is due primarily to intrapulmonary shunting and } \\
\text { typically persists despite high concentrations of inhaled oxygen }\end{array}$ \\
\hline
\end{tabular}

Abbreviation: $\mathrm{V} / \mathrm{Q}$, ventilation/perfusion. 
rely heavily on anaerobic metabolism. Hyperventilation, which is subjectively perceived as dyspnea, is present at rest and increases excessively during exercise because augmentation of the right-to-left shunt induced by exercise is accompanied by an increase in systemic arterial carbon dioxide and a decrease in $\mathrm{pH}$ that stimulate the respiratory center and carotid bodies. ${ }^{34}$

6. Dyspnea in tetralogy of Fallot (TOF): Isotonic exercise is accompanied by a fall in systemic vascular resistance in the presence of fixed obstruction to right ventricular outflow, increasing venoarterial mixing, and significantly influencing the dynamics of $\mathrm{O}_{2}$ uptake and ventilation. Exercise-induced hypoxemia and increased carbon dioxide content stimulate the respiratory center and the carotid body, provoking hyperventilation that is subjectively perceived as dyspnea.

Mechanism of relief of dyspnea by squatting in TOF patientThe mechanisms by which squatting exerts its beneficial effects are as follows. Quiet standing after exercise-induced peripheral vasodilation predisposes to orthostatic hypotension and faintness, a tendency exaggerated in hypoxemic patients. Squatting counteracts orthostatic hypotension and diminishes or prevents postexertion orthostatic faintness. Squatting increases systemic vascular resistance, diverts right ventricular blood into the pulmonary circulation, and increases the amount of oxygenated blood entering the left side of the heart. The left ventricle delivers the larger volume of oxygenated blood into the systemic circulation, so systemic arterial $\mathrm{PO}_{2}$ and $\mathrm{pH}$ increase and $\mathrm{PCO}_{2}$ decreases, blunting the stimulus to the respiratory center and carotid body and relieving hyperventilatory dyspnea. The effect of squatting on systemic venous return is an even more effective means by which hyperventilatory dyspnea is relieved. Isotonic leg exercise reduces the oxygen saturation of venous effluent returning to the heart from the lower extremities. Squatting mechanically curtails lower extremity venous return, decreases the volume of unsaturated venous blood delivered to the heart, and increases the oxygen saturation of right ventricular blood. Right ventricular blood shunted into systemic circulation has higher oxygen content and $\mathrm{pH}$ and lower $\mathrm{PCO}_{2}$ content. The higher $\mathrm{PO}_{2}$ and $\mathrm{pH}$ and the lower $\mathrm{PCO}_{2}$ reduce the stimulus to the respiratory center and carotid body and reduce the hyperventilatory dyspnea. ${ }^{35}$

7. Eisenmenger's ductus: Isotonic exercise with an Eisenmenger's ductus causes leg fatigue without dyspnea because an exercise-induced increase in right-to-left shunt is channeled into the descending aorta distal to the respiratory center and the carotid body, precluding hypoxia-induced stimulation. ${ }^{36}$

8. Tricuspid atresia: Hypoxic spells precipitated by a reduction in size or spontaneous closure of a restrictive ventricular septal defect (VSD) are characterized by sudden deepening of cyanosis followed by paroxysmal dyspnea, lethargy, and syncope. Older children squat for relief of breathlessness. ${ }^{37}$

9. Pulmonary arteriovenous (AV) fistulas: Blood flow through pulmonary AV fistulae is affected by mechanical factors. Flow through lower lobe fistulae is augmented in the upright position because of increased perfusion of dependent portions of the lungs. A decubitus position compresses the dependent lung and reduces blood flow through an ipsilateral fistula. A case in point was a large pulmonary AV fistula in an infant in whom ipsilateral chest wall compression was therapeutic, immediately decreasing the cyanosis and relieving the dyspnea. Elevation of the diaphragm during pregnancy can compress a lower lobe fistula and abolish the accompanying murmur, which reappears after delivery. ${ }^{38}$ Dyspnea and fatigue do not correspond to the degree of cyanosis but are related to anemia caused by bleeding hemorrhagic telangiectasia.

10. Dextro-transposition of the great arteries (DTGA): In transposition of the great arteries (TGA), pulmonary venous baffle obstruction causes elevated PA pressure, and patients can present with dyspnea and pulmonary venous congestive features. ${ }^{39}$

11. Corrected TGA (CTGA): In CTGA, VSD patch, and LV to PA conduit repair, most patients are in functional class $I$ at 5 to 10 years after surgery despite the common development of systemic tricuspid regurgitation and systemic right ventricular dysfunction after surgical repair. Dyspnea, exercise intolerance, and palpitations from supraventricular arrhythmia often occur in the fourth decade. ${ }^{40}$

12. Prosthetic valve: In prostatic valve implanted patients, thrombosis of the prosthetic valve should be suspected by the sudden appearance of dyspnea.

\section{Precipitating Factors for Dyspnea}

1. Exertion.

2. Posture.

3. Consumption of a heavy meal or small amounts of alcohol can also transiently increase subaortic gradient and produce dyspnea. Furthermore, a large proportion of HCM patients without outflow obstruction (or systolic anterior motion [SAM]) at rest may generate outflow gradients with physiologic exercise, sometimes associated with severe heart failure symptoms. Fully $70 \%$ of a hospital-based HCM cohort have the propensity to develop an outflow gradient $\geq 30 \mathrm{~mm} \mathrm{Hg}$, either at rest or during exercise. ${ }^{41}$

4. Drug induced: Nonsteroidal anti-inflammatory drugs (NSAIDs)/glitazones causing fluid retention and worsening of pulmonary venous hypertension.

\section{Treatment}

The treatment is influenced by the etiology (respiratory/ cardiac/neuromuscular disease) and mechanisms of dyspnea.

1. Supplemental $\mathrm{O}_{2}$ should be administered if the resting $\mathrm{O}_{2}$ saturation is $\leq 89 \%$ or if the patient's saturation drops to these levels with activity.

2. Pulmonary edema-IV diuretics, vaso, and vasodilators. Check the complete treatment in textbooks.

3. Experimental interventions-for example cold air on the face, chest wall vibration, and inhaled furosemide-aimed 
at modulating the afferent information from receptors throughout the respiratory system are being studied.

4. Morphine has been shown to reduce dyspnea out of proportion to the change in ventilation in laboratory models.

\section{Dyspnea as Indication to Start Therapy}

In atrial fibrillation (AF), favorable candidates for electrical cardioversion of AF include patients who have symptoms of decreased cardiac output (e.g., fatigue, light-headedness, dyspnea) attributable to lack of atrial contraction's contribution to ventricular filling. 42

\section{Dyspnea as a Marker for Prognosis}

In a coronary artery disease (CAD) patient, there is increased risk after normal SPECT has also been reported in patients with dyspnea as the presenting symptom. ${ }^{43}$

\section{Conflict of Interest}

None.

\section{References}

1 Kasper DL, Harrison TR. Dyspnea. In: Harrison's Principles of Internal Medicine. 19th ed. New York, NY: McGraw-Hill; 2015:chap 47e, p. 243

2 Hurst JW, Fuster V, Walsh RA, Harrington RA. The history, physical examination, and cardiac auscultation. In: Hurst's the Heart. New York, NY: McGraw-Hill; 2011:chap 14, p. 247

3 Hurst JW, Fuster V, Walsh RA, Harrington RA. Pathophysiology of heart failure. In: Hurst's the Heart. New York, NY: McGraw-Hill; 2011:chap 26, p. 733

4 Mann DL, Zipes DP, Libby P, Bonow RO. The history and physical examination: an evidence-based approach. In: Braunwald's Heart Disease: A Textbook of Cardiovascular Medicine. 9th ed. Philadelphia, PA: Elsevier/Saunders; 2011:chap 12, p. 107

5 Hurst JW, Fuster V, Walsh RA, Harrington RA. The epidemiology and diagnosis of heart failure. In: Hurst's the Heart. New York, NY: McGraw-Hill; 2011:chap 27, p. 740

6 Mann DL, Zipes DP, Libby P, Bonow RO. The history and physical examination: an evidence-based approach. In: Braunwald's Heart Disease: A Textbook of Cardiovascular Medicine. 9th ed. Philadelphia, PA: Elsevier/Saunders; 2011:chap 12, p. 108

7 Mann DL, Zipes DP, Libby P, Bonow RO. Pulmonary hypertension. In: Braunwald's Heart Disease: A Textbook of Cardiovascular Medicine. 9th ed. Philadelphia, PA: Elsevier/ Saunders; 2011:chap 78, p. 1707

8 Hurst JW, Fuster V, Walsh RA, Harrington RA. Pulmonary hypertension. In: Hurst's the Heart. New York, NY: McGraw-Hill; 2011:chap 71, pp. 1609-1633

9 Mann DL, Zipes DP, Libby P, Bonow RO. Pericardial diseases. In: Braunwald's Heart Disease: A Textbook of Cardiovascular Medicine. 9th ed. Philadelphia, PA: Elsevier/Saunders; 2011:chap 75, p 1656

10 Anderson RH, Baker JE, Redington A, Rigby LM, Penny D, Wernovsky G. Management of congenital heart disease in pregnancy. In: Paediatric Cardiology. 3rd ed. Philadelphia, PA: Churchill Livingstone Elsevier; 2010:chap 60, p. 1228

11 Allen HD, Shaddy RE, Penny DJ, Feltes TF, Cetta F. Exercise testing. In: Moss \& Adams' Heart Disease in Infants, Children, and Adolescents, Including the Fetus and Young Adult. 9th ed. Philadelphia, PA: Wolters Kluwer Health; 2016:chap 7, p. 127

12 Allen HD, Shaddy RE, Penny DJ, Feltes TF, Cetta F. Echocardiography: basic principles and imaging. In: Moss \& Adams'
Heart Disease in Infants, Children, and Adolescents, Including the Fetus and Young Adult. 9th ed. Philadelphia, PA: Wolters Kluwer Health; 2016:chap 8, p. 164

13 Mann DL, Zipes DP, Libby P, Bonow RO. Unstable angina non-ST elevation myocardial infarction. In: Braunwald's Heart Disease: A Textbook of Cardiovascular Medicine. 9th ed. Philadelphia, PA: Elsevier/Saunders; 2011:chap 56, p. 1189

14 Anderson RH, Baker JE, Redington A, Rigby LM, Penny D, Wernovsky G. Pharmacological and interventional fetal cardiovascular treatment. In: Paediatric Cardiology. 3rd ed. Philadelphia, PA: Churchill Livingstone Elsevier; 2010: chap 12, p. 201

15 Anderson RH, Baker JE, Redington A, Rigby LM, Penny D, Wernovsky G. Pharmacological and interventional fetal cardiovascular treatment. In: Paediatric Cardiology. 3rd ed. Philadelphia, PA: Churchill Livingstone Elsevier; 2010: chap 12, p. 206

16 Allen HD, Shaddy RE, Penny DJ, Feltes TF, Cetta F. Exercise testing. In: Moss \& Adams' Heart Disease in Infants, Children, and Adolescents, Including the Fetus and Young Adult. 9th ed. Philadelphia, PA: Wolters Kluwer Health; 2016: chap 7, p. 119

17 Mann DL, Zipes DP, Libby P, Bonow RO. The history and physical examination: an evidence-based approach. In: Braunwald's Heart Disease: A Textbook of Cardiovascular Medicine. 9th ed. Philadelphia, PA: Elsevier/Saunders, 2011: chap 12, p. 118

18 Mann DL, Zipes DP, Libby P, Bonow RO. Congenital heart disease. In: Braunwald's Heart Disease: A Textbook of Cardiovascular Medicine. 9th ed. Philadelphia, PA: Elsevier/ Saunders; 2011: chap 65, p. 1428

19 Joseph PAM. Congenital aortic stenosis: congenital aortic regurgitation. In: Clinical Recognition of Congenital Heart Disease: Expert Consult. Philadelphia, PA: Elsevier/Saunders; 2012: chap 7, p. 80

20 Mann DL, Zipes DP, Libby P, Bonow RO. Stable ischemic heart disease. In: Braunwald's Heart Disease: A Textbook of Cardiovascular Medicine. 9th ed. Philadelphia, PA: Elsevier/ Saunders; 2011: chap 57, p. 1210

21 Mann DL, Zipes DP, Libby P, Bonow RO. Stable ischemic heart disease. In: Braun Wald's Heart Disease: A Textbook of Cardiovascular Medicine. 9th ed. Philadelphia, PA: Elsevier/ Saunders; 2011.: chap 57, p. 1243

22 Mann DL, Zipes DP, Libby P, Bonow RO. Echocardiography. In: Braunwald's Heart Disease: A Textbook of Cardiovascular Medicine. 9th ed. Philadelphia, PA: Elsevier/Saunders; 2011: chap 16, p. 224, 230

23 Mann DL, Zipes DP, Libby P, Bonow RO. Echocardiography. In: Braunwald's Heart Disease: A Textbook of Cardiovascular Medicine. 9th ed. Philadelphia, PA: Elsevier/Saunders; 2011: chap 16, p. 248

24 Mann DL, Zipes DP, Libby P, Bonow RO. Endocrine disorders and cardiovascular diseases. In: Braunwald's Heart Disease: A Textbook of Cardiovascular Medicine. 9th ed. Philadelphia, PA: Elsevier/Saunders; 2011:chap 86, p. 1836

25 Mann DL, Zipes DP, Libby P, Bonow RO. Management of heart failure patients with reduced ejection fraction. In: Braunwald's Heart Disease: A Textbook of Cardiovascular Medicine. 9th ed. Philadelphia, PA: Elsevier/Saunders; 2011.:chap 28, p. 549

26 Drazner MH, Hellkamp AS, Leier CV, et al. Value of clinician assessment of hemodynamics in advanced heart failure: the ESCAPE trial. Circ Heart Fail 2008;1(3):170-177

27 Mann DL, Zipes DP, Libby P, Bonow RO. Electrocardiography. In: Braunwald's Heart Disease: A Textbook of Cardiovascular Medicine. 9th ed. Philadelphia, PA: Elsevier/Saunders; 2011:chap 13, p. 166

28 Mueller C, Scholer A, Laule-Kilian K, et al. Use of B-type natriuretic peptide in the evaluation and management of acute dyspnea. N Engl J Med 2004;350(7):647-654 
29 Mann DL, Zipes DP, Libby P, Bonow RO. Management of heart failure patients with reduced ejection fraction. In: Braunwald's Heart Disease: A Textbook of Cardiovascular Medicine. 9th ed. Philadelphia, PA: Elsevier/Saunders; 2011:chap 28, p. 575

30 Allen HD, Shaddy RE, Penny DJ, Feltes TF, Cetta F. Anomalies of the pulmonary veins. In: Moss \& Adams' Heart Disease in Infants, Children, and Adolescents, Including the Fetus and Young Adult. 9th ed. Philadelphia, PA: Wolters Kluwer Health; 2016:chap 35, p. 831

31 Allen HD, Shaddy RE, Penny DJ, Feltes TF, Cetta F. Pericardial diseases. In: Moss \& Adams' Heart Disease in Infants, Children, and Adolescents, Including the Fetus and Young Adult. 9th ed. Philadelphia, PA: Wolters Kluwer Health; 2016: chap 62, p. 1354

32 Hurst JW, Fuster V, Walsh RA, Harrington RA. Mitral valve regurgitation.In: Hurst's the Heart. New York, NY: McGraw-Hill; 2011:chap 77, p. 1729

33 Joseph PAM. Atrial septal defect: simple and complex. In: Clinical Recognition of Congenital Heart Disease: Expert Consult. Philadelphia, PA: Elsevier/Saunders, 2012:chap 15, p. 220

34 Joseph PAM. Ventricular septal defect. In: Clinical Recognition of Congenital Heart Disease: Expert Consult. Philadelphia, PA: Elsevier/Saunders; 2012: chap 17, p. 292

35 Joseph PAM. Ventricular septal defect with pulmonary stenosis. In: Clinical Recognition of Congenital Heart Disease: Expert Consult. Philadelphia, PA: Elsevier/Saunders; 2012:chap 18, p. 326

36 Joseph PAM. Clinical Recognition of Congenital Heart Disease: Expert Consult, Chapter 20 Patent Ductus Arteriosus
Aortopulmonary Window, p. 373. Philadelphia, PA: Elsevier/ Saunders, 2012

37 Joseph PAM. Tricuspid atresia. In: Clinical Recognition of Congenital Heart Disease: Expert Consult. Philadelphia, PA: Elsevier/Saunders; 2012: chap 25, p. 444

38 Joseph PAM. Congenital pulmonary arteriovenous fistula. In: Clinical Recognition of Congenital Heart Disease: Expert Consult. Philadelphia, PA: Elsevier/Saunders; 2012:chap 30, p. 515

39 Mann DL, Zipes DP, Libby P, Bonow RO. Congenital heart disease. In: Braunwald's Heart Disease: A Textbook of Cardiovascular Medicine. 9th ed. Philadelphia, PA: Elsevier/Saunders; 2011:chap 65, p. 1446

40 Mann DL, Zipes DP, Libby P, Bonow RO. Congenital heart disease. In: Braunwald's Heart Disease: A Textbook of Cardiovascular Medicine. 9th ed. Philadelphia, PA: Elsevier/Saunders; 2011: chap 65, p. 1448

41 Mann DL, Zipes DP, Libby P, Bonow RO. Hypertrophic cardiomyopathy. In: Braunwald's Heart Disease: A Textbook of Cardiovascular Medicine. 9th ed. Philadelphia, PA: Elsevier/ Saunders; 2011.:chap 69, p. 1586

42 Mann DL, Zipes DP, Libby P, Bonow RO. Therapy for cardiac arrhythmias. In: Braunwald's Heart Disease: A Textbook of Cardiovascular Medicine. 9th ed. Philadelphia, PA: Elsevier/Saunders; 2011:chap 30, p. 729

43 Hurst JW, Fuster V, Walsh RA, Harrington RA. Nuclear cardiology. In: Hurst's the Heart. New York, NY: McGraw-Hill; 2011:chap 21, p. 576 